\title{
ROUTING RUNOFF AND SOIL PARTICLES IN A DISTRIBUTED MODEL WITH GIS: IMPLICATIONS FOR SOIL PROTECTION IN MOUNTAIN AGRICULTURAL LANDSCAPES
}

\author{
M. LÓPEZ-VICENTE ${ }^{*}$ and A. NAVAS \\ Department of Soil and Water, Experimental Station of Aula Dei - CSIC. Avda. Montañana \\ 1005, 50059 Zaragoza, Spain. \\ * Corresponding author: Tel.: +34 976-716-107; Fax: +34 976-716-145; \\ E-mail: mvicente@eead.csic.es; mlopezvicente@gmail.com
}
---- Published on Land Degradation \& Development 21(2), 100-109, DOI: 10.1002/ldr.901 (26 March 2010) ----
---- Published online 30 January 2009 in Wiley InterScience ----
---- Received 23 September 2008; Accepted 5 December 2008 ----

\begin{abstract}
Soil erosion by water is a serious threat to crop sustainability and one of the main causes of landscape degradation in Mediterranean environments. The accurate assessment of soil erosion is a first requirement to face the problem of soil loss in highly fragile mountain environments. In this work, simple flow (D8), multiple flow (MD) and combined flow (MDD8) algorithms are used to compute cumulative runoff. Effective runoff is estimated after accounting infiltration and soil surface properties and added to the revised Morgan, Morgan and Finney (RMMF) model of soil erosion at the "Laguna Grande de Estaña" catchment (Spanish pre-Pyrenees). The combined flow algorithm explicitly associated to the gullies (MDD8-G) leads to a more realistic assessment of runoff pathways. The MD algorithm generates unrealistic maps of concentrated runoff in gullies and overestimates soil erosion rates (average rate of $75 \mathrm{Mg} \mathrm{ha}^{-1} \mathrm{yr}^{-1}$ ). The D8 and MDD8-G algorithms estimate similar values of soil erosion (average rates at catchment scale of 37 and $44 \mathrm{Mg} \mathrm{ha}^{-1} \mathrm{yr}^{-1}$, respectively). Paths, crops on steep slopes, open Mediterranean forest and sparse scrublands have the highest values of soil erosion (more than $50 \mathrm{Mg} \mathrm{ha}^{-1} \mathrm{yr}^{-1}$ ). The estimated rates with the MDD8-G algorithm in control points in crops, forest and scrublands fit better with available data from ${ }^{137} \mathrm{Cs}$ than those
\end{abstract}


obtained with the D8 algorithm. Therefore, the MDD8-G algorithm improves the quality predictions of soil erosion and is of interest to study processes of overland flow in Mediterranean environments with presence of gullies.

KEY WORDS: runoff; soil erosion; RMMF model; flow accumulation algorithm; GIS; gully; Mediterranean agrosystem; Spain

\section{INTRODUCTION}

Soil loss in productive croplands produced by rainfall splash and overland flow is a serious environmental and economic problem in many Mediterranean environments causing both on- and offsite effects (Bou Kheir, 2008). The loss of fertile soil in arable lands and the degradation in the quality of the soil resources are the main on-site consequences of soil erosion (Morgan, 2005). Siltation of water bodies is an important off-site impact of soil erosion (Navas et al., 2004). The extent of soil erosion in some Spanish regions has caused great concern regarding the sustainability of soil resources. Field measurements of soil loss demonstrate the influence of lithology, land use and climate on the spatial variability of soil erosion rates (Navas et al., 2007). To tackle this problem the European Union (EU) recently presented the soil protection and amending framework (COM, 2006) and directive (EPC, 2004). These documents are the first specific Community legislation on soil protection and establish a common strategy for the protection and sustainable use of soil based on the principles of integration of soil. The Commission of the European Communities considers soil as essentially a nonrenewable resource and identifies that soil degradation has strong impacts on areas of common interest, such as water, human health, climate change, nature and biodiversity protection, and food safety. Positive effects on the state of agricultural soils are also expected to result from the European Union soil protection and amending framework and directive and from the reformed Common Agricultural Policy (MAPA, 2004). Therefore, the accurate assessment of runoff volume and soil erosion is required by the EU, especially in soil erosion-sensitive areas such as the Mediterranean agrosystems.

Accurate mapping of runoff pathways is fundamental in modelling the spatial redistribution of water and sediment at slope and catchment scales. Distributed predictions of runoff allow identifying initiation of linear erosion at the divides (Chaplot et al., 2005) and are useful to assess soil erosion and pollutant transport (Granlund, 
2004). Computations of flow direction and accumulation with different routing algorithms improve spatial predictions of soil erosion and deposition models (Vigiak et al., 2006). Estimations of concentrated flow, upslope contributing area and soil erosion are dependent on the type of routing algorithm used to calculate the split or concentration of runoff and sediment along the landscape (Endreny and Wood, 2001; Takken et al., 2005) and the spatial resolution of the digital elevation model (DEM) (Clarke and Lee, 2007). However, the reliability of model predictions with flow accumulation algorithms at catchment scale has seldom been validated against observations, especially in ungauged watersheds.

Some geoforms such as gullies, rills and gorges describe processes of soil erosion by water that can be considered before running models of overland flow and soil erosion and deposition. Accurate spatial quantification of runoff volume in gullies may lead to realistic spatially predictions of soil erosion in productive areas where soils are under fragile conditions such as in Mediterranean agrosystems. Moreover, the use of accurate flow accumulation algorithms and the improvement of the available algorithms is one of the most relevant topics in current hydrological research in soil sciences.

Mediterranean landscapes have been intensively modified by human being and are characterized by contrasted climate with irregular but frequently intense rainy episodes, sparse vegetation cover and multiple land uses where soils are generally poorly developed and vulnerable to erosion (Machín and Navas, 1995). In these landscapes the loss of fertile soil in croplands (Brenot et al., 2008) is a serious threat to their sustainable use and economic exploitation. Hence, accurate spatially distributed modelling and quantification of runoff and soil loss at catchment scale is of interest to promote conservation policies for wetlands as well as to implement better management practices (BMPs) for Mediterranean soil and water resources.

This research aims to model the effective runoff volume and soil erosion rates in the "Estanque Grande de Abajo" catchment (Central Spanish Pre-Pyrenees) as well as to assess the performance of different flow accumulation algorithms to quantify these processes. To this purpose the distributed revised Morgan, Morgan and Finney (RMMF) model of soil erosion (Morgan, 2001) and a simple, a multiple and a combined flow accumulation algorithms are used to predict spatially distributed rates of runoff and soil loss. The combined algorithm is modified with field measured data of the location of 
gullies to account the different processes of overland flow concentration along the hillslope. Annual values of runoff and soil loss are calculated for the whole catchment and for the different land uses and areas surrounding the lake with the different algorithms. Available data of soil loss quantified with ${ }^{137} \mathrm{Cs}$ at several control points near the lake and under different land uses are used to compare the estimations of soil erosion with the different algorithms. The study area allows assessing the accuracy of the different algorithms of flow accumulation because this catchment constitutes a closed-hydrological-system.

\section{MATERIALS AND METHODS}

\section{Study area}

The "Estanque Grande de Abajo" catchment (120 ha) is the largest sub-catchment within the Estaña catchment (Huesca, NE Spain) (Figure 1) and is located in the southern limit of the External Ranges of the Central Pre-Pyrenees, close to the northern boundary of the Ebro basin. The study area includes one lake (15 ha) and a wetland area that are under protection by the regional government since 1997 and included in the European NATURA 2000 network as Site of Community Importance (SCI). However, the intensive agriculture during the last centuries, the practices of land abandonment in the $\mathrm{XX}^{\text {th }}$ century and the European Union policy of set-aside during the last decades could endanger the conservation of this protected area. Morellón et al. (2008) estimated after radiocarbon dating of sediment cores collected in the "Estanque Grande de Abajo" lake a siltation rate of $2.3 \mathrm{~mm} \mathrm{yr}^{-1}$ for the last 800 years. This time interval represents a period under continuous land cultivation that is representative of the current land uses.

The climate is continental Mediterranean with two rainy periods in Spring and Autumn and a dry summer with frequent rainfall events of high intensity (LópezVicente et al., 2008a). The average annual precipitation was $595 \mathrm{~mm}$ for the period 1993-2006 with an average minimum and maximum temperature of 6.0 and $18.8^{\circ} \mathrm{C}$, respectively (Figure 1) (López-Vicente, 2008). The study area is underlayed by limestones and gypsiferous marls, dolostones and occasionally salt deposits. Karstic processes partially control the evolution of the landscape. The elevation ranges from 676 to $872 \mathrm{~m}$ a.s.1. with a mean slope of $17 \%$ and steep slopes ( $>22.5 \%$ ) occupy $26 \%$ of the total surface. The geomorphic units of the study area were identified by López- 
Vicente et al. (2009) and include two collapse dolines that are associated to the lake, one uvala, nine gullies with a maxima length of 323 meters and a main stream that measures 1421 meters, together with the presence of colluvial, alluvial and doline deposits (Figure 1).

The land uses of the study area are representative of Mediterranean mountain agrosystems and fifteen different land uses are identified. Crops of rainfed winter barley are the main land-use (36\% of the total surface). The rest are dense and open Mediterranean forest (19 and 16\%), dense scrublands (7\%) and recently abandoned fields $(5 \%)$. Other land uses occupies less than $5 \%$ of the total surface and are spread around the study area (Figure 1). Areas of bare soil correspond to outcrops of massive gypsum either boulder grounds and soil erosion modelling has been excluded because the RMMF model does not simulate erosion processes in rocks.

\section{Estimation of annual erosion with RMMF and flow accumulation algorithms}

The semi-physically based RMMF model (Morgan, 2001) estimates the annual rates of soil detachment by splash $\left(F ; \mathrm{Mg} \mathrm{ha}^{-1} \mathrm{yr}^{-1}\right)$ and runoff $\left(H ; \mathrm{Mg} \mathrm{ha}^{-1} \mathrm{yr}^{-1}\right)$ and compares the total rate of detachment with the runoff transport capacity (TC; $\mathrm{Mg} \mathrm{ha}^{-1} \mathrm{yr}^{-1}$ ) to calculate the annual values of soil erosion $\left(E ; \mathrm{Mg} \mathrm{ha}^{-1} \mathrm{yr}^{-1}\right)$ (Figure 2).

$$
E=\min \{(F+H), T C\}
$$

This model is a more complete approach than the previous Morgan, Morgan and Finney (MMF) model (Morgan et al., 1984) and has been applied in many plots and catchments in several countries and under different climatic conditions and land use scenarios (e.g. Morgan, 2001; Vigiak et al., 2006; López-Vicente et al., 2008b; Scholz et al., 2008). This model does not consider transport of soil particle by raindrop-impact either the effect of crust on soil surface that are relatively frequent in Mediterranean landscapes.

\section{Estimation of rainfall energy}

Effective rainfall $(E R, \mathrm{~mm})$ is estimated after accounting the way total annual rainfall $(R ; \mathrm{mm})$ is partitioned during interception $(A ; 0-1)$. The effective rainfall is split into direct throughfall $(D T ; \mathrm{mm})$, which directly reaches the soil surface and leaf drainage $(L D ; \mathrm{mm})$, that is intercepted by the plant canopy and reaches the ground by stemflow 
or dripping from leaves. The split is a direct function of the percentage canopy cover (CC).

$$
\begin{aligned}
& E R=R A \\
& L D=E R C C \\
& D T=E R-L D
\end{aligned}
$$

In this work, the kinetic energy of the direct throughfall rainfall $\left(E(D T) ; \mathrm{J} \mathrm{m}^{-2}\right)$ was determined using the equation of Coutinho and Tomás (1995) developed in southern Portugal and considered suitable for western Mediterranean areas. This equation estimates the kinetic energy of the rain $\left(K E ; \mathrm{J} \mathrm{m}^{-2} \mathrm{~mm}^{-1}\right)$ as a function of the rainfall intensity $\left(I ; \mathrm{mm} \mathrm{h}^{-1}\right)$. The kinetic energy of the leaf drainage $\left(E(L D) ; \mathrm{J} \mathrm{m}^{-2}\right)$ is dependent upon the height of the plant canopy $(\mathrm{PH} ; \mathrm{m})$ and the total energy of the effective rainfall $\left(E ; \mathrm{J} \mathrm{m}^{-2}\right)$ equals the addition of $E(D T)$ and $E(L D)$.

$$
\begin{aligned}
& E(D T)=D T K E=D T 35.9[1-0.559 \exp (-0.034 I)] \\
& E(L D)=\left(15.8 P H^{0.5}\right)-5.87 \\
& E=K E(D T)+K E(L D)
\end{aligned}
$$

Where Eq. (5) yields a negative value, $E(L D)$ is assumed to be zero.

\section{Estimation of runoff}

The RMMF model computes the annual volume of runoff per raster cell $(Q ; \mathrm{mm})$ assuming that runoff occurs when the mean rain per erosive rain day $\left(R_{0} ; \mathrm{mm}\right)$ exceeds the soil moisture storage capacity $\left(R_{c} ; \mathrm{mm}\right)$ :

$$
\begin{aligned}
& Q=R \exp \left(\frac{-R_{C}}{R_{0}}\right) \\
& R_{C}=1000 \mathrm{MSBDVol} \text { eff }_{E} E H D\left(\frac{E T_{a}}{E T_{0}}\right)^{0.5}
\end{aligned}
$$

Where $M S$ is the soil moisture content at field capacity $\left(\% \mathrm{w} \mathrm{w}^{-1}\right), B D$ is the bulk density of the soil $\left(\mathrm{Mg} \mathrm{m}^{-3}\right), V_{\text {eff }}$ is the effective volume of the soil (value between 0 1), $E H D$ is the effective hydrological depth of the soil (m) and $E T_{a} / E T_{0}$ is the ratio between actual and potential evapotranspiration. The effective volume is related to the volume of the soil that actual retains water and is considered to be the same as that occupied by the soil fraction with a grain size of less than $2 \mathrm{~mm}$ (Soto and Navas, 
2004). The term EHD indicates the depth of soil within which the moisture storage capacity controls the generation of runoff as a function of the plant cover. Values of EHD correspond to those included in the RMMF model (Morgan, 2001) for the different land-uses (Table I).

\section{Estimation of effective runoff}

Rainfall becomes overland flow after top-soil is saturated and strongly depends on the distribution of rainfall and soil properties (Mugabe et al., 2007). The effective runoff $(D Q)$ is defined as the rainfall which is neither retained on the land surface nor infiltrated into the soil and becomes overland flow until it is drained in one of the catchment channels Chow et al. (1988). The effective runoff volume was then computed from the potential cumulative overland flow $\left(D Q_{0} ; \mathrm{mm}\right)$, the saturated hydraulic conductivity of the different soils $\left(K_{f s} ; \mathrm{mm} \mathrm{day}^{-1}\right)$, the maximum soil surface storage capacity $\left(S S_{\max } ; \mathrm{mm}\right)$ and slope steepness $(S ;$ degree $)$.

Traditionally, the most widely used method to compute cumulative runoff is the simple flow algorithm (D8) (Vigiak et al., 2006). In this method water and materials in a cell can flow to only one of its neighbors. The multiple flow algorithm (MD) avoids these errors and offers a more realistic mapping of the flow pattern. Moreover, the recently developed combined algorithm (MDD8, Schäuble, 2005) assumes the MD routine until reaches a threshold value and then the flow pattern is calculated as for the D8 algorithm. This threshold value represents the beginning of ephemeral streams and gullies and provides a better description of the pathways of runoff and transport of soil particles.

In this work, the D8, MD and MDD8 algorithms were used to estimate the potential cumulative overland flow from the original value of $Q$ and by using the Sediment Yield Tools 1.03 extension for ArcView 3.2 GIS. Vigiak et al. (2006) proved the usefulness of a semi-distributed hydrological approach (based on the D8 algorithm) in Tanzania to estimate the spatial patterns of erosion with the RMMF model obtaining a correct simulation at around $75 \%$.

After detailed field observations of the initiation of the gullies and their situation in the DEM from the divides, a threshold value of runoff volume was established in the combined flow algorithm (MDD8-G) as representative of the actual change from 
multiple to linear flow into the gullies. The hydrological process simulated in this work was successfully applied by López-Vicente et al. (2008b) in cultivated fields of the Estaña catchment and by de Jong et al. (1999) in a large catchment in Sicily (Italy).

$$
\begin{aligned}
& D Q=\left(D Q_{0}-K_{f s}-S S_{\text {max }}\right) \sin S \\
& S S_{\text {max }}=0.5 R G \frac{\sin ^{2}(S I G-S)}{\sin (S I G)} \cdot \frac{\cot (S I G+S)+\cot (S I G-S)}{2 \cos (S I G) \cos (S)}
\end{aligned}
$$

where $R G(\mathrm{~mm})$ is the surface roughness, $S$ (radian) is the slope steepness and $S I G$ (radian) is the angle of the surface soil and surface furrow. The maximum surface storage capacity was calculated according to Driessen (1986). A SIG value of $30^{\circ}$ was considered valid for the study area based on Terzoudi et al. (2007). Surface roughness is the configuration of the soil caused by the randomly orientated arrangement of soil clods. Tillage tools can produce random roughness and orientated roughness. In this work values of $R G$ proposed by Renard et al. (1997) are used for forest areas (random roughness, $R G=20.3 \mathrm{~mm})$ and for cultivated fields with plough $(R G=48.3 \mathrm{~mm})$ and field cultivator $(R G=17.8 \mathrm{~mm})$.

A correction was made to the different maps of effective runoff for the ephemeral streams because erosion by overland flow stops as soon as the overland flow reaches the stream. To account this effect the estimated volume of runoff at the beginning of the gullies is considered as the maximum runoff volume.

\section{Soil particle detachment by raindrop impact}

Detachment of soil particle by raindrop impact $\left(F ; \mathrm{Mg} \mathrm{ha}^{-1} \mathrm{yr}^{-1}\right)$ is computed from the total rainfall energy and the parameter of soil erodibility $\left(K ; \mathrm{g} \mathrm{J}^{-1}\right)$.

$$
F=K K E 10^{-2}
$$

Values of $K$ are obtained from Morgan (2001) for the different types of soil textures.

\section{Soil particle detachment by runoff}

The RMMF model estimates the detachment of soil by runoff $\left(H ; \mathrm{Mg} \mathrm{ha}^{-1} \mathrm{yr}^{-1}\right)$ as a function of runoff volume, slope steepness $(S$; radian) and the resistance of the soil $(Z$; $\left.\mathrm{kPa}^{-1}\right)$.

$$
H=Z D Q^{1.5} \sin S(1-G C) 10^{-2}
$$




$$
Z=\frac{1}{0.5 \mathrm{COH}}
$$

where $G C$ is the percentage of ground cover and includes crop residues and rocks and $\mathrm{COH}(\mathrm{kPa})$ is the cohesion of the soil. Values of $G C$ are obtained from the percentage of coarse fragments and percentage of soil surface covered by crop residues in barley fields (Renard et al., 1997). Values of cohesion were obtained from Morgan (2001) for the different textures of the soil. For loose, non-cohesive soils, $Z=1.0$. Equation (13) assumes that soil detachment by runoff only occurs where the soil is not protected by ground cover.

\section{Runoff transport capacity}

The transport capacity of runoff (TC; $\mathrm{Mg} \mathrm{ha}^{-1} \mathrm{yr}^{-1}$ ) is computed from the effective runoff volume $(D Q)$, the slope steepness $(S)$ and the $C$ and $P$ factors of the RUSLE model (Renard et al., 1997). The $C$ factor deals with the soil and crop management whereas the $P$ factor computes the support practices.

$$
T C=C P D Q^{2} \sin S 10^{-2}
$$

\section{Soil sampling and data collection}

Rainfall daily values generated at the reconstructed Estaña weather station for the period $1993-2006$ are used to characterize the annual precipitation $(R=595 \mathrm{~mm})$, whereas rainfall data recorded at 15 minutes at the Canelles weather station are used to calculate the typical value of rainfall intensity $\left(I=15.1 \mathrm{~mm} \mathrm{~h}^{-1}\right)$ and the mean annual rainfall per erosive rainday $\left(R_{0}=35.9 \mathrm{~mm}\right)$. The parameters of rainfall interception, canopy cover, plant height and the ratio between actual and potential evapotranspiration are the proposed by López-Vicente (2008) for the different land uses of the study area. Values of effective hydrological depth correspond to those values proposed by Machín et al. (2008) for the different soil types described in the catchment and range between 0 and $0.25 \mathrm{~m}$.

A total of 118 soil samples were collected. Samples were air-dried, grinded, homogenized and quartered to pass through a $2 \mathrm{~mm}$ sieve and the weight percentage of coarse fragments was calculated. Laser equipment was used to determine the textural class of each sample. Values of bulk density, stoniness, sand, silt and clay content and 
soil moisture content at field capacity were measured and soil detachability and soil cohesion were estimated. Slope steepness and length and potential cumulative overland flow were calculated using the enhanced digital elevation model (DEM) of the study area (López-Vicente et al., 2009). Values of the $C$ and $P$ factors of the RUSLE model correspond to those estimated by López-Vicente and Navas (2009) for the study area.

Before running the RMMF model a mask associated to the gullies was created within a Geographic Information System (GIS) and values of the parameters $A, C C$, $G C, E H D, E T_{a} / E T_{0}$ and $C$ equal to those proposed for areas with no vegetation cover. This mask aims to represent the special conditions of the soil into the gullies, where soil surface is directly affected by splash and runoff without almost any kind of protection. The maps of the corresponding properties were created with the assistant of the Spline interpolator method that fits a minimum-curvature surface through the input points. All maps, the interpolation and the mathematical operations were done with the ArcView GIS 3.2 ${ }^{\circledR}$ and ArcGIS 9.0 ${ }^{\circledR}$ applications at high spatial resolution (cell size $=5 \times 5 \mathrm{~m}$ ).

\section{RESULTS AND DISCUSSION}

The maps of potential and effective runoff obtained with the three algorithms present many differences in both their spatial pattern and values (Figure 3) (Table II). The simple D8 algorithm creates many drainage artifacts and parallel flowpaths that are unrealistic according to field observations. The MD algorithm generates wide streams that disagree with the actual size of the channel of the gullies in the study area. The MDD8-G algorithm produces the most realistic spatial pattern of runoff due to its direct relation with the gullies of the study area. The estimated value of maximum runoff volume at the initiation site of the gullies is $16586 \mathrm{~mm}$.

Maps of distributed soil loss also present a high spatial variability and differences in the estimated erosion rates between the different approaches (Figure 3). The mean values of soil loss at catchment scale are 36.7, 75.2 and 44.2 $\mathrm{Mg} \mathrm{ha}^{-1} \mathrm{yr}^{-1}$ estimated with the D8, MD and MDD8-G algorithms, respectively. These values are similar to those values measured with microtopographic profiles by Benito et al. (1992) in badlands in the External Ranges of the Spanish Pyrenees (rates between 24 and $485 \mathrm{Mg} \mathrm{ha}^{-1}$ for a period between 7 and 15 months, respectively) under similar weather conditions. However, the estimated erosion rates at the study area are much higher than that 
proposed by De la Horra (1992) in Central Spain as the rate of tolerable soil erosion under Mediterranean conditions (6 $\mathrm{Mg} \mathrm{ha}^{-1} \mathrm{yr}^{-1}$ ) and are also higher than the average erosion rate (27 $\mathrm{Mg} \mathrm{ha}^{-1} \mathrm{yr}^{-1}$ ) estimated by ICONA (1980-1990) for Spain.

Areas with low (less than $4 \mathrm{Mg} \mathrm{ha}^{-1} \mathrm{yr}^{-1}$ ) and tolerable (between 4 and $8 \mathrm{Mg} \mathrm{ha}^{-1} \mathrm{yr}^{-}$ ${ }^{1}$ ) values of soil loss represent 54,37 and $50 \%$ of the study area with the estimations of the D8, MD and MDD8-G algorithms, respectively. Areas with no erosion occupy 14, 3 and $4 \%$ of the total study area for the D8, MD and MDD8-G algorithms, respectively and are mainly located at the beginning of the flowpaths and in flat areas. Rates of runoff transport capacity were lower than those of total soil detachment in 85,69 and $80 \%$ of the study area with the D8, MD and MDD8-G algorithms, respectively. Runoff transport capacity is the main limiting factor that controls the estimated values of soil loss. These results agree with field observations reported by several authors (e.g. Lecce et al., 2006) finding that most of the soil erosion and sediment yield is explained by intense runoff events. To improve the predictions of the modified RMMF model, further research may focus in modifying the concentration factor of the MDD8-G algorithm to include the monthly variations in runoff volume and transport capacity, especially in the months of May, August, September and October when heavy storm events are frequent in the study area (López-Vicente et al., 2008a). Moreover, the inclusion of parameters for a better description of changes in runoff transport capacity due to the increasing amount of sediment load from divides to the slope bottom is also recommended.

Annual soil erosion rates were calculated for the different land uses with the three algorithms (Table II). Prediction values of soil loss with the D8 and the MDD8-G algorithms are similar and much lower than those values obtained with the MD algorithm (Figure 3). The spatially distributed results of runoff volume and soil erosion rates obtained with the MD algorithm disagree with those obtained with the D8 and with field observations of processes of concentrated overland flow. Therefore, the MD algorithm is non suitable to model runoff and soil erosion processes in this abrupt study area.

Paths, crops on steep slopes, open Mediterranean forest and sparse scrubland have very high rates of erosion (higher than $50 \mathrm{Mg} \mathrm{ha}^{-1} \mathrm{yr}^{-1}$ ) and should be controlled in the context of preservation of the fragile wetland of the singular Mediterranean environment of the Estaña catchment. Pastures and oak forest present very low erosion 
rates (less than $2 \mathrm{Mg} \mathrm{ha}^{-1} \mathrm{yr}^{-1}$ ). The average erosion rate in areas modified by human activities (crops, abandoned fields, orchards and paths) is 39.3 and $48.9 \mathrm{Mg} \mathrm{ha}^{-1} \mathrm{yr}^{-1}$ estimated with the D8 and MDD8-G algorithms, respectively. These values are higher than those erosion rates estimated in areas covered by forest, shrubs and seed grass with average values of 34.4 and $40.0 \mathrm{Mg} \mathrm{ha}^{-1} \mathrm{yr}^{-1}$ estimated with the D8 and MDD8-G algorithms, respectively. These results highlight the key role of human disturbances in the natural cycle of soil erosion and agree with the observations described by Navas et al. (2005) in some mountain areas of the Pyrenees where the main cause of soil degradation has been identified as a consequence of deforestation, overgrazing, extensive agriculture since the Middle Ages and land abandonment since the beginning of the $20^{\text {th }}$ century. De Santisteban et al. (2006) measured in cereal $\left(2-115 \mathrm{Mg} \mathrm{ha}^{-1} \mathrm{yr}^{-}\right.$ $\left.{ }^{1}\right)$ and recently abandoned fields $\left(162 \mathrm{Mg} \mathrm{ha}^{-1} \mathrm{yr}^{-1}\right)$ in northern Spain similar values of soil erosion as those estimated in crops and abandoned fields of the study area.

The statistical analysis by multiple regression between the estimated erosion rates and the inputs of the modified RMMF model shows that only the canopy cover, slope and flow length significantly affect the variation of erosion rates $(p \leq 0.05)$. These results agree with those obtained by García-Ruiz et al. (2008) in three small catchments in Central Spanish Pyrenees where plant cover is a key factor influencing the different temporal and spatial processes of soil erosion and redistribution.

The estimated erosion rates with the D8 and MDD8-G algorithms are compared with available data on erosion rates measured by López-Vicente et al. (2008b) by using fallout ${ }^{137} \mathrm{Cs}$ in cultivated fields that surround the lake (Figure 1). On an ongoing research in the Estaña catchment ${ }^{137} \mathrm{Cs}$ profiles show high soil erosion rates in crops on steep slopes and low rates in dense Mediterranean forest and dense scrubland (Navas, personal communication) (Table III). A number of control points (10) were chosen as representative of the different physiographic conditions of the study area and were selected for comparison with estimations from modified RMMF model with the D8 and MDD8-G algorithms. In general, in most of the control points the erosion rates compares well although it is necessary to consider that predicted values are modelled for a raster cell area of 5 x 5 meters. The D8 algorithm underestimates soil erosion by $34 \%$ whereas with the MDD8-G algorithm values of soil loss are $27 \%$ higher than that quantified with ${ }^{137} \mathrm{Cs}$ at the sampling point (Table III). Quantified erosion rates with 
${ }^{137} \mathrm{Cs}$ means the processes of soil loss and deposition that have happened during the last four decades, whereas the predicted rates with the RMMF model accounts the average annual rates. Nonetheless, the consistency of the validation between both techniques is basis on the fact the land-uses and climate have not suffered any significant change during the last four decades.

The comparison between predicted and available ${ }^{137} \mathrm{Cs}$ rates at control points suggest that the combined flow algorithm related to the gullies is suitable to improve the estimations of annual rates of soil erosion. Because of the need for preserving wetlands in Mediterranean environments the first requirement is to improve quantitative estimations of eroded soil that can reach water bodies. On the other hand, the lower erosion rates found in the areas with dense vegetation suggests that either natural regrowth or re-forestation of the erodible-areas especially in the low-productive crops located on steep slopes will minimize the siltation of wetlands.

\section{CONCLUSIONS}

Flow algorithms are of interest to quantify potential accumulated runoff. Accurate estimations of soil infiltration and surface properties improve the predictions of spatially distributed runoff. The maps of effective runoff computed with the simple, multiple and combined flow algorithms present great variation of both their spatial patterns and values and thus their predicted rates of soil detachment and transport capacity by runoff.

The combined flow algorithm related to the gullies provides a more realistic representation of the flow patterns through the gullies of the study area and improves the spatial quantification of runoff in comparison with the simple and multiple flow algorithms. The MD algorithm does not generate accurate maps of flow accumulation especially in gullies and overestimates the effective runoff volume and soil erosion rates.

The D8 and MDD8-G flow algorithms predict similar values of soil erosion for the different land uses though estimations of soil loss with the MDD8-G algorithm fit better with available rates from ${ }^{137} \mathrm{Cs}$. Therefore, the MDD8-G algorithm leads the modified RMMF model to a more reliable assessment of soil erosion and consequently on their affections on wetlands in Mediterranean environments. The application of this algorithm is recommended for mapping concentrated runoff volume and soil erosion in 
agrosystems affected by gullies to improve the quality of their spatial predictions. The information gained with this research can be applied to other agricultural Mediterranean landscapes for better identification of the main erosion-sensitive areas in order to prevent land degradation. Because of the high supply of sediments from the cultivated fields land conservation measures and best management practices are highly recommended for croplands.

\section{ACKNOWLEDGEMENTS}

This research was funded by the CICYT Project CGL2005-02009/BTE.

\section{REFERENCES}

Benito G, Gutiérrez M, Sancho C. 1992. Erosion Rates in Badland Areas of the Central Ebro Basin (NE-Spain). Catena 19: 269-286.

Bou Kheir R. 2008. A conditional GIS-interpolation-based model for mapping soil-water erosion processes in Lebanon. Land Degradation \& Development 19: 122-135.

Brenot J, Quiquerez A, Petit C, Garcia J-P. 2008. Erosion rates and sediment budgets in vineyards at 1-m resolution based on stock unearthing (Burgundy, France). Geomorphology: doi:10.1016/j.geomorph.2008.01.005.

Chaplot V, Giboire G, Marchand P, Valentin C. 2005. Dynamic modelling for linear erosion initiation and development under climate and land-use changes in northern Laos. Catena 63: $318-328$

Chow VT, Maidment DR, Mays LW. 1988. Applied Hydrology. McGraw-Hill, New York, 572 pp.

Clarke KC, Lee SJ. 2007. Spatial resolution and algorithm choice as modifiers of downslope flow computed from digital elevation models. Cartography and Geographic Information Science 34: 215-230.

COM (Commission of the European Communities). 2006. Proposal for a Directive of the European Parliament and of the Council establishing a framework for the protection of soil and amending Directive 2004/35/EC (presented by the Commission). COM(2006) 232 final. 2006/0086 (COD). Brussels, Belgium.

Coutinho MA, Tomás PP. 1995. Characterization of raindrop size distributions at the Vale Formoso Experimental Erosion Center. Catena 25: 187-197. 
De la Horra JL. 1992. Aspectos biogeográficos en relación con la problemática agraria de la comarca de Torrijos (Toledo) / Biogeographic aspects in relation with the problemmatic agricultura in Torrijos. Ph.D. Thesis, Universidad Complutense de Madrid, Spain.

de Jong SM, Paracchini ML, Bertolo F, Folving S, Megier J, de Roo APJ. 1999. Regional assessment of soil erosion using the distributed model SEMMED and remotely sensed data. Catena 37: 291-308.

De Santisteban LM, Casalí J, López JJ. 2006. Assessing soil erosion rates in cultivated areas of Navarre (Spain). Earth Surface Processes and Landforms 31: 487-506.

Driessen PM. 1986. The water balance of soil. In van Keulen, H. and Wolf, J. (eds.), Modeling of Agricultural Production: Weather, Soils and Crops, Pudoc, Wageningen, The Netherlands, pp. 76-116.

Endreny TA, Wood EF. 2001. Representing elevation uncertainty in runoff modeling and flowpath mapping. Hydrological Processes 15: 2223-2236.

EPC (European Parliament and of the Council). 2004. Directive 2004/35/CE of the European Parliament and of the Council of 21 April 2004 on environmental liability with regard to the prevention and remedying of environmental damage. Official Journal of the European Union L 143/56.

García-Ruiz JM, Regüés D, Alvera B, Lana-Renault N, Serrano-Muela P, Nadal-Romero E, Navas A, Latron J, Martí-Bono C, Arnáez J. 2008. Flood generation and sediment transport in experimental catchments affected by land use changes in the central Pyrenees. Journal of Hydrology 356: 245- 260.

Granlund K. 2004. Variation of runoff and nitrogen leaching in a small agricultural catchment in southern Finland. Nordic Hydrology 35: 335-345.

ICONA. 1980-1990. Mapas de Estados Erosivos. Cuencas Hidrográficas del Ebro, Guadiana, Guadalquivir, Júcar, Pirineo, Segura, Sur de España, Tajo,.... ICONA, Ministerio de Agricultura, Pesca y Alimentación. Madrid, Spain.

Lecce SA, Pease PP, Gares PA, Wang J. 2006. Seasonal controls on sediment delivery in a small coastal plain watershed, North Carolina, USA. Geomorphology 73: 246-260.

López-Vicente M. 2008. Erosión y redistribución del suelo en agroecosistemas mediterráneos: Modelización predictiva mediante SIG y validación con ${ }^{137}$ Cs (Cuenca de Estaña, Pirineo Central) / Soil erosion and redistribution in Mediterranean agro-ecosystems: predictive modelling with GIS and validation with ${ }^{137}$ Cs (Estaña catchment, Spanish Central Pyrenees). University of Zaragoza. Zaragoza, Spain. 212 pp.

López-Vicente M, Navas A. 2009. Predicting soil erosion with RUSLE in Mediterranean agricultural systems at catchment scale. Soil Science 174(5): 272-282. 
López-Vicente M, Navas A, Machín J. 2008a. Identifying erosive periods by using RUSLE factors in mountain fields of the Central Spanish Pyrenees. Hydrology and Earth System Sciences 12(2): 523-535.

López-Vicente M, Navas A, Machín J. 2008b. Modelling soil detachment rates in rainfed agrosystems in the south-central. Agricultural Water Management 95(9): 1079-1089.

López-Vicente M, Navas A, Machín J. 2009. Geomorphic mapping in endorheic subcatchments in the Spanish Pyrenees: an integrated GIS analysis of topographic-karstic features. Geomorphology 111(1-2): 38-47.

Machín J, Navas A. 1995. Land evaluation and conservation of semiarid agrosystems in Zaragoza (NE Spain) using an expert evaluation system and GIS. Land Degradation \& Development 6(4): 203-214.

Machín J, López-Vicente M, Navas A. 2008. Cartografía digital de suelos de la Cuenca de Estaña (Prepirineo Central) / Digital soil mapping of the Estaña catchment (Spanish Central Pre-Pyrenees). Proceedings X Reunión Nacional de Geomorfología, Cádiz, Spain.

MAPA (Ministerio de Agricultura, Pesca y Alimentación). 2004. Real Decreto 2352/2004, de 23 de diciembre, sobre la aplicación de la condicionalidad en relación con las ayudas directas en el marco de la política agrícola común. Boletín Oficial del Estado. Madrid, Spain.

Morellón M, Valero-Garcés B, Moreno A, González-Sampériz P, Mata P, Romero O, Maestro M, Navas A. 2008. Holocene palaeohydrology and climate variability in northeastern Spain: The sedimentary record of Lake Estanya (Pre-Pyrenean range). Quaternary International 181(1): 15-31.

Morgan RPC. 2001. A simple approach to soil loss prediction: a revised Morgan-MorganFinney model. Catena 44(4): 305-322.

Morgan RPC. 2005. Soil Erosion and Conservation, $3^{\text {rd }}$ Edition. Blackwell Publishing: Cornwall, United Kingdom.

Morgan RPC, Morgan DDV, Finney HJ. 1984. A predictive model for the assessment of erosion risk. Journal of Agricultural Engineering Research 30: 245-253.

Mugabe FT, Hodnett MG, Senzanje A. 2007. Effect of temporal rainfall distribution and soil type on soil moisture and runoff generation in semi-arid Zimbabwe. Nordic Hydrology 38: 249-263.

Navas A, Machín J, Soto J. 2005. Assessing soil erosion in a Pyrenean mountain catchment using GIS and fallout ${ }^{137} \mathrm{Cs}$. Agriculture Ecosystems \& Environment 105: 493-506. 
Navas A, Valero-Garcés BL, Machín J. 2004. An approach to integrated assessement of reservoir siltation: the Joaquín Costa reservoir as case study. Hydrology and Earth System Sciences 8: 1193-1199.

Navas A, Walling DE, Quine T, Machín J, Soto J, Domenech S, López-Vicente M. 2007. Variability in ${ }^{137} \mathrm{Cs}$ inventories and potential climatic and lithological controls in central Ebro valley, Spain. Journal of Radioanalytical and Nuclear Chemistry 274(2): 331-339.

Renard KG, Foster GR, Weesies GA, McCool DK, Yoder DC. 1997. Predicting Soil Erosion by Water: A Guide to Conservation Planning with the Revised Universal Soil Loss Equation (RUSLE). Handbook \#703. US Department of Agriculture, Washington, DC.

Schäuble H. 2005. Sedimentfrachtprognosen mit GIS - Neue Strategien für globale Modellgleichungen unter besonderer Berücksichtigung von Staudämmen und des zeitlichen Wandels. Dissertation. Institut für Angewandte Geowissenschften, Technische Universität Darmstadt, Darmstadt, Germany.

Scholz G, Quinton JN, Strauss P. 2008. Soil erosion from sugar beet in Central Europe in response to climate change induced seasonal precipitation variations. Catena 72: 91-105.

Soto J, Navas A. 2004. A model of ${ }^{137}$ Cs activity profile for soil erosion studies in uncultivated soils of Mediterranean environments. Journal of Arid Environments 59: 719-730.

Takken I, Govers G, Jetten V, Nachtergaele J, Steegen A, Poesen J. 2005. The influence of both process descriptions and runoff patterns on predictions from a spatially distributed soil erosion model. Earth Surface Processes and Landforms 30: 213-229.

Terzoudi CB, Gemtos TA, Danalatos NG, Argyrokastritis I. 2007. Applicability of an empirical runoff estimation method in central Greece. Soil \& Tillage Research 92: 198-212.

Vigiak O, Sterk G, Romanowicz RJ, Beven KJ. 2006. A semi-empirical model to assess uncertainty of spatial patterns of erosion. Catena 66: 198-210. 
Table I Values of potential (DQ $)$ and effective (DQ) runoff volume estimated with the D8, MD and MDD8-G algorithms for the "Estanque Grande de Arriba" catchment (NE Spain).

\begin{tabular}{|c|c|c|c|c|c|c|c|c|}
\hline \multirow[t]{3}{*}{ Type of algorithm } & \multicolumn{4}{|c|}{$\mathrm{DQ}_{0}$} & \multicolumn{4}{|c|}{ DQ } \\
\hline & mean & $\min$ & $\max$ & SD & mean & $\min$ & $\max$ & SD \\
\hline & \multicolumn{4}{|c|}{$\mathrm{mm}$} & \multicolumn{4}{|c|}{$\mathrm{mm}$} \\
\hline D8 & 4662 & 156 & 16586 & 5568 & 671 & 0 & 11080 & 1091 \\
\hline MD & 8790 & 230 & 16586 & 5821 & 1334 & 0 & 11080 & 1332 \\
\hline MDD8-G & 5539 & 230 & 16586 & 4352 & 815 & 0 & 11080 & 910 \\
\hline
\end{tabular}

Table II Mean annual erosion rates estimated with the modified RMMF model and the different flow algorithms for the different land uses at the "Estanque Grande de Abajo" catchment.

\begin{tabular}{|c|c|c|c|c|c|c|}
\hline \multicolumn{2}{|c|}{ Type of land use } & \multicolumn{2}{|c|}{ Area } & \multicolumn{3}{|c|}{ Estimated soil loss } \\
\hline & & & \multirow{3}{*}{$\begin{array}{l}\% \\
1.7\end{array}$} & D8 & MD & MDD8-G \\
\hline & & & & \multicolumn{3}{|c|}{$\mathrm{Mg} \mathrm{ha}^{-1} \mathrm{yr}^{-1}$} \\
\hline Anthropogenic & Path & & & 98.3 & 171.7 & 120.9 \\
\hline \multirow[t]{6}{*}{ land-use } & Crops in steep slopes & 22.0 & 21.0 & 49.8 & 100.9 & 63.2 \\
\hline & Crops in gentle areas & 15.3 & 14.6 & 29.3 & 63.2 & 35.6 \\
\hline & Pasture & 0.5 & 0.5 & 0.6 & 0.6 & 0.4 \\
\hline & Orchard & 0.5 & 0.5 & 24.0 & 49.3 & 34.6 \\
\hline & Old abandoned field & 3.5 & 3.3 & 9.2 & 19.9 & 7.8 \\
\hline & Recent abandoned field & 5.5 & 5.3 & 35.7 & 63.1 & 43.9 \\
\hline \multirow{8}{*}{$\begin{array}{l}\text { Natural } \\
\text { vegetation }\end{array}$} & Oak forest & 3.3 & 3.1 & 1.4 & 2.2 & 1.2 \\
\hline & Dense Mediterranean forest & 20.3 & 19.4 & 18.2 & 39.5 & 17.9 \\
\hline & Open Mediterranean forest & 16.5 & 15.8 & 73.0 & 153.4 & 89.2 \\
\hline & Dense scrubland & 7.5 & 7.2 & 8.6 & 15.3 & 9.5 \\
\hline & Sparse scrubland & 3.2 & 3.1 & 48.2 & 92.1 & 54.1 \\
\hline & Poplar & 0.3 & 0.3 & 41.6 & 79.8 & 44.5 \\
\hline & Bank vegetation & 3.9 & 3.7 & 19.1 & 40.7 & 23.1 \\
\hline & Area without soil (outcrops) & 0.6 & 0.6 & - & - & - \\
\hline
\end{tabular}


Table III Comparison of erosion rates estimated with the modified RMMF model and the D8 and MDD8-G flow algorithms and available data quantified with ${ }^{137} \mathrm{Cs}$ at different control points in crops, dense forest and scrublands.

\begin{tabular}{|c|c|c|c|c|}
\hline \multirow[t]{3}{*}{ Type of land use } & \multirow[t]{2}{*}{ Control point } & \multirow{2}{*}{$\begin{array}{c}\text { Quantified soil loss } \\
{ }^{137} \mathrm{Cs}\end{array}$} & \multicolumn{2}{|c|}{ Estimated soil loss } \\
\hline & & & D8 & MDD8-G \\
\hline & ID & $\mathrm{Mg} \mathrm{ha}^{-1} \mathrm{yr}^{-1}$ & \multicolumn{2}{|c|}{$\mathrm{Mg} \mathrm{ha}^{-1} \mathrm{yr}^{-1}$} \\
\hline \multirow[t]{3}{*}{ Crops in gentle areas } & 1 & 5.7 & 16.9 & 20.2 \\
\hline & 2 & 2.5 & 6.6 & 11.5 \\
\hline & 3 & 4.3 & 3.6 & 13.1 \\
\hline \multirow[t]{3}{*}{ Crops on steep slopes } & 4 & 100.5 & 84.6 & 20.2 \\
\hline & 5 & 24.3 & 0.8 & 13.5 \\
\hline & 6 & 22.6 & 1.0 & 121.1 \\
\hline \multirow[t]{3}{*}{ Dense Mediterranean forest } & 7 & 2.4 & $<0.1$ & 0.8 \\
\hline & 8 & 3.1 & 0.3 & 7.3 \\
\hline & 9 & 5.1 & 0.6 & 14.4 \\
\hline Dense scrubland & 10 & 4.0 & $<0.1$ & $<0.1$ \\
\hline
\end{tabular}


Figure 1 Geographic situation of the study area in NE Spain and mean monthly values of rainfall at the Estaña reconstructed weather station. Map of land uses of the study area and illustrations of gully erosion.
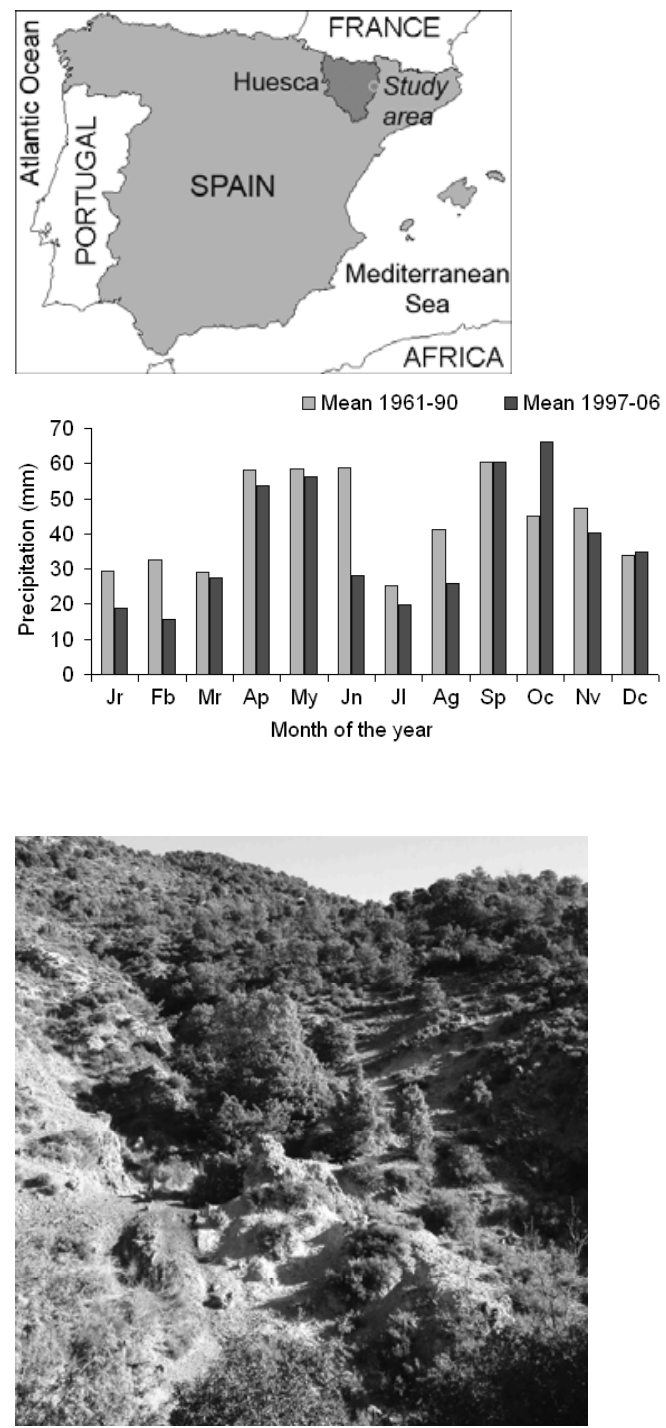
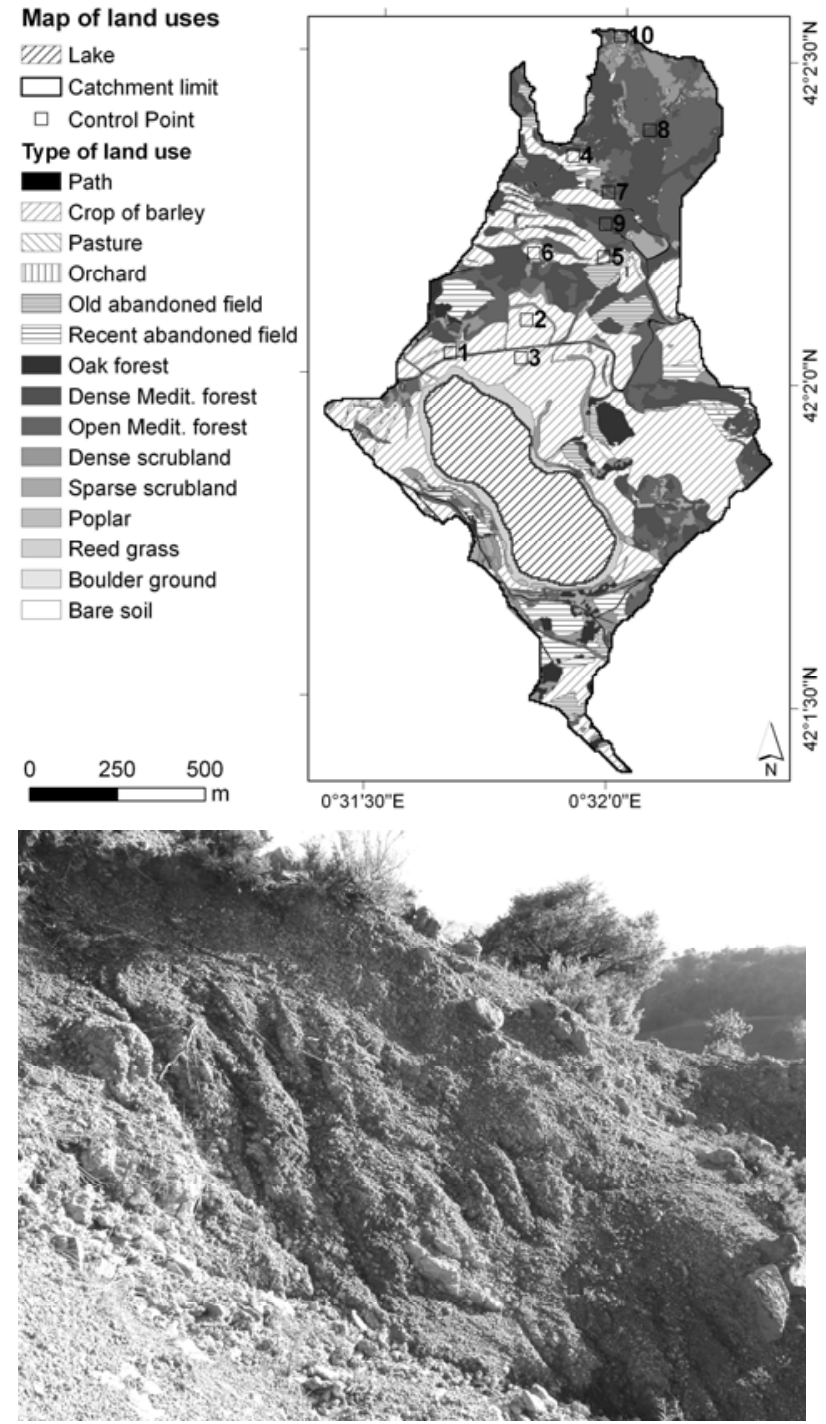
Figure 2 Flowchart of the modified RMMF model with the flow accumulation algorithms. Gray figures correspond to the modifications included in this work.

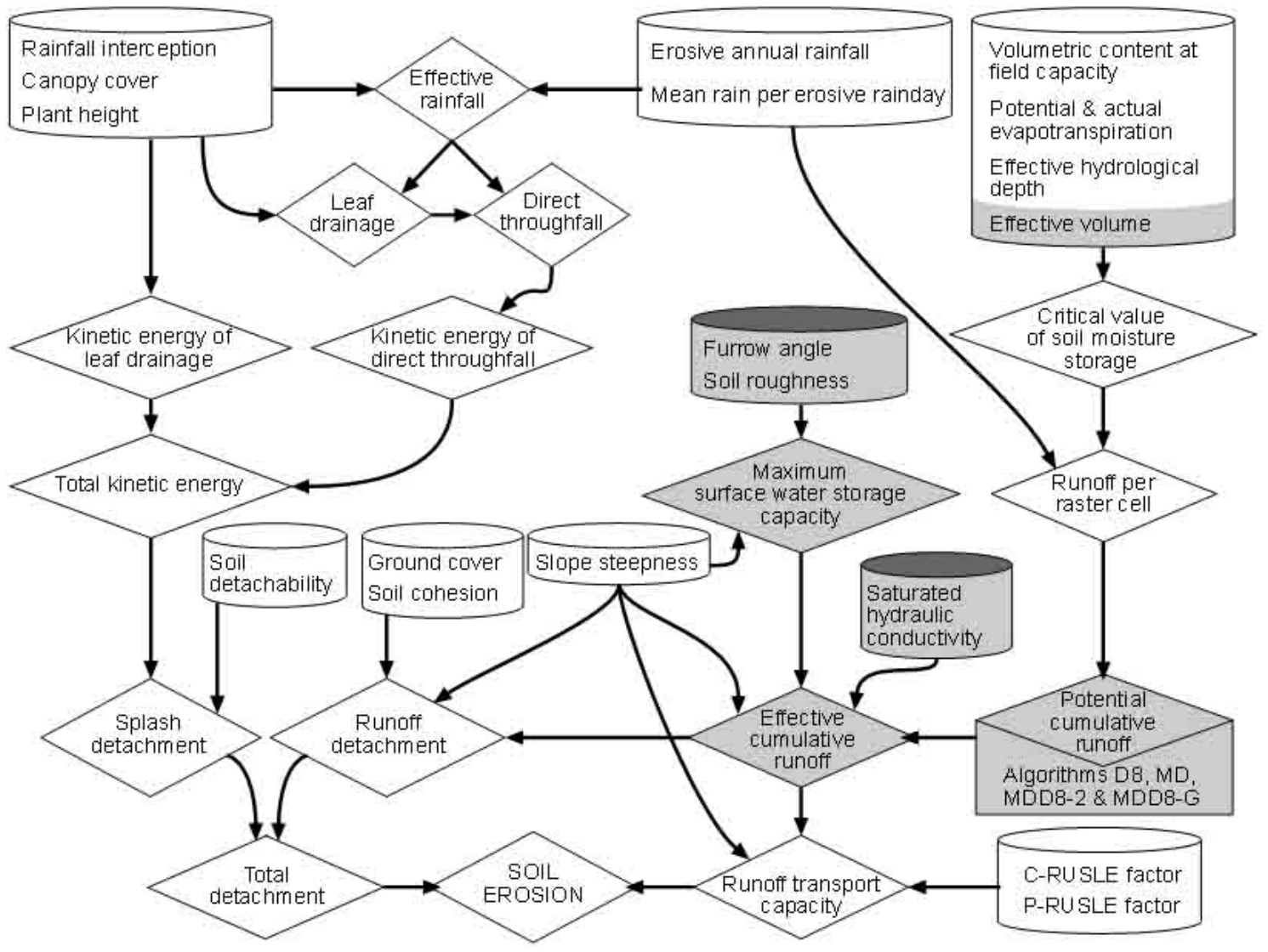


1 Figure 3 Maps of effective runoff and soil erosion estimated with the modified RMMF model and the D8, MD and MDD8-G flow accumulation algorithms.
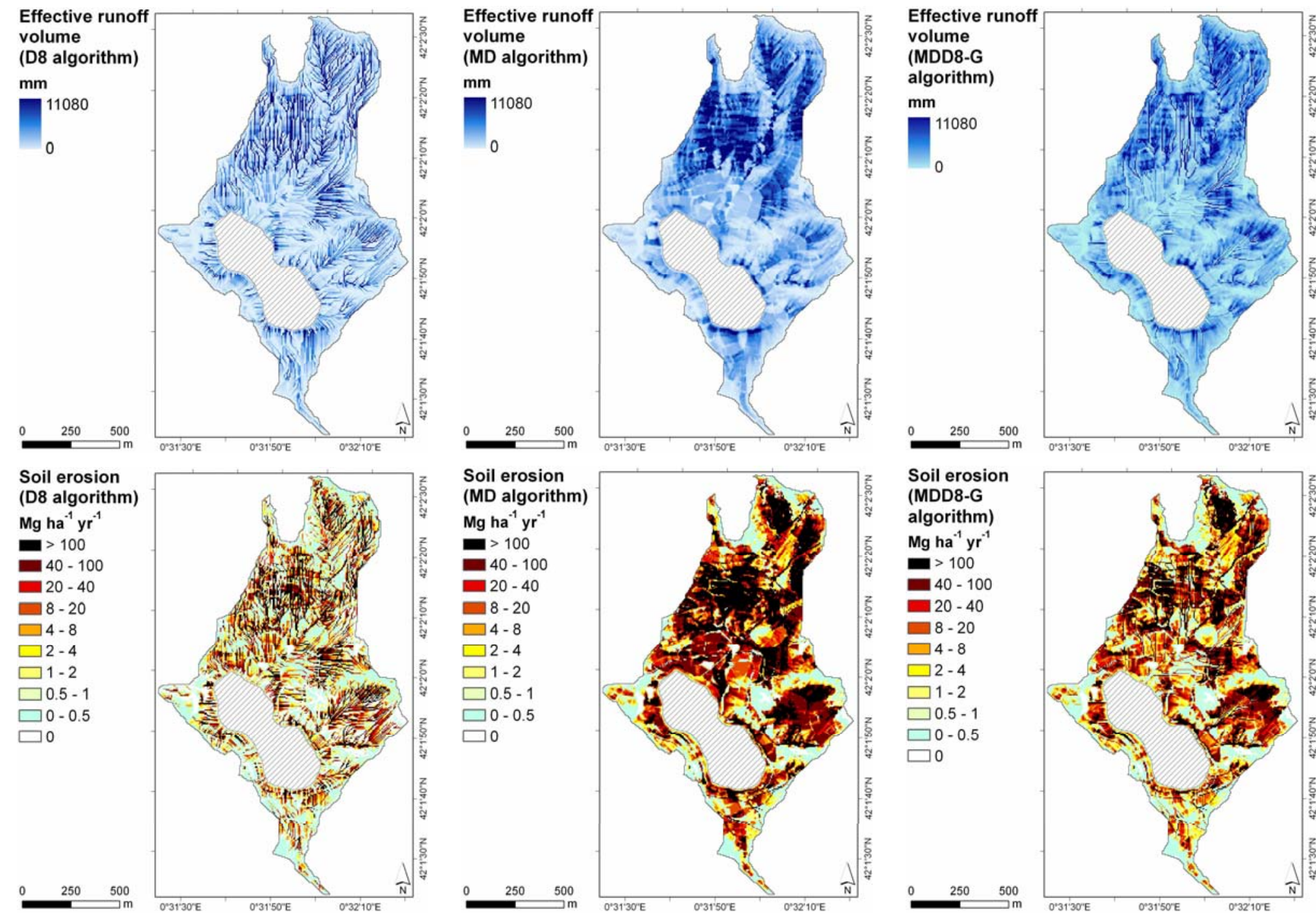